\title{
PENGARUH HARGA BAHAN BAKU, HARGA JUAL DAN PRODUKSI TERHADAP HASIL PENJUALAN TAHU DI KECAMATAN LANGSA KOTA
}

\author{
Hanisah $^{1}$, Dolly Rivani ${ }^{2}$ \\ ${ }^{1}$ Dosen Fakultas Pertanian Universitas Samudra \\ ${ }^{2}$ Mahasiswa Program Studi Agribisnis Fakultas Pertanian Universitas Samudra
}

\begin{abstract}
Abstrak
Tujuan penelitian untuk mengetahui pengaruh harga bahan baku, harga jual dan produksi terhadap hasil penjualan tahu di Kecamatan Langsa Kota. Penelitian ini dilakukan dengan mengunakan metode survei. Penelitian ini merupakan studi kasus pada usaha tahu di Kecamatan Langsa Kota. Objek penelitian adalah pengusaha tahu yang terdapat di Kecamatan Langsa Kota. Ruang lingkup penelitian terbatas pada pengaruh harga bahan baku, harga jual dan produksi terhadap hasil penjualan tahu di Kecamatan Langsa Kota. Penelitian dilaksanakan pada bulan Desember 2017 s/d Januari 2018.

Dari hasil penelitian diperoleh bahwa hasil analisis regresi linier berganda diperoleh persamaan regresi : $\mathrm{Y}=-5,325+0,002 \mathrm{X}_{1}+0,239 \mathrm{X}_{2}+0,221 \mathrm{X}_{3}$. Nilai $\mathrm{R}^{2}$ sebesar 0,999 artinya bahwa variabel harga bahan baku, harga jual dan produksi mempengaruhi hasil penjualan pada usaha tahu di Kecamatan Langsa Kota sebesar 99,9\%. Sisanya sebesar 0,1\% dipengaruhi faktor lain yang tidak dimasukan dalam model penelitian ini seperti biaya produksi, promosi, sistem

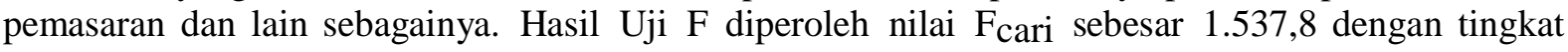
significan 0,000 maka secara serempak variabel harga bahan baku, harga jual dan produksi berpengaruh sangat nyata terhadap hasil penjualan pada usaha tahu di Kecamatan Langsa Kota. Hasil uji t diperoleh nilai tcari $\mathrm{X}_{1}$ sebesar 0,60 dengan significan 0,954 maka secara terpisah harga bahan baku tidak berpengaruh terhadap hasil penjualan. Hasil uji t diperoleh $t_{c a r i} \mathrm{X}_{2}$ sebesar 11,665 dengan significan 0,000 , maka secara terpisah harga jual berpengaruh sangat nyata terhadap hasil penjualan. Hasil uji t3 diperoleh $t_{c a r i} X_{3}$ sebesar 10,274 dengan significan 0,000 maka secara terpisah produksi berpengaruh sangat nyata terhadap hasil penjualan pada usaha tahu di Kecamatan Langsa Kota.
\end{abstract}

Kata Kunci: Bahan Baku, Harga Jual, Produksi, Hasil Penjualan

\section{Pendahuluan}

Tahu merupakan makanan olahan yang dibuat dari kedelai dan digemari oleh hampir seluruh lapisan masyarakat. Tahu mempunyai kandungan gizi yang sangat beragam yang dibutuhkan oleh tubuh. Kandungan gizi tahu dapat menggantikan gizi yang berasal dari hewan berupa telur dan daging.

Kota Langsa merupakan salah satu kota yang berada di Provinsi Aceh dengan penduduk yang memiliki latar belakang budaya yang beragam. Tahu merupakan jenis makanan olahan dari kedelai yang disukai oleh hampir sumua masyarakat yang ada di Kota Langsa. Peluang permintaan tahu memunculkan usaha kecil pembuatan tahu di Kota Langsa.

Harga bahan baku tahu adalah harga bahanbahan yang digunakan pada pembuatan produk tahu. Bahan baku utama pembuatan tahu adalah kacang kedelai atau dikenal dengan kacang kuning. Harga kedelai menentukan besarnya biaya produksi usaha pembuatan tahu dan besarnya keuntungan yang akan diperoleh pengusaha tahu.

Harga jual tahu adalah harga tahu yang ditetapkan oleh pengusaha tahu kepada konsumen dengan dasar biaya produksi yang dikeluarkan selama proses produksi pengolahan kedelai menjadi tahu. Harga jual tahu mengikuti dari biaya produksi yang didalamnya terdiri dari biaya tetap dan biaya variabel. Biaya tetap yaitu biaya yang tidak habis selama sekali proses produksi seperti biaya penyusutan alat dan sewa tempat usaha. Biaya variabel yaitu biaya yang habis dalam sekali proses produksi seperti bahan baku, tenaga kerja dan bahan bakar. 
Produksi adalah produksi usaha tahu dalam bentuk tahu perpapan yang siap dipasarkan ke konsumen atau pedagang penegecer. Produksi tahu yang dihasilkan pengusaha tahu erat kaitannya dengan hasil penjualan sehingga akan mempengaruh pendapatan pengusaha tahu. Berdasarkan uraian di atas penulis tertarik melakukan penelitian tentang pengaruh harga bahan baku, harga jual dan produksi terhadap hasil penjualan tahu di Kota Langsa, sedangkan faktor lainnya dianggap tetap.

\section{Tujuan}

Tujun Penelitian ini untuk mengetahui pengaruh harga bahan baku, harga jual dan produksi terhadap hasil penjualan tahu di Kecamatan Langsa Kota.

\section{Penelitian}

"Harga bahan baku, harga jual dan produksi berpengaruh terhadap hasil penjualan tahu di Kecamatan Langsa Kota”.

\section{Metodologi Penelitian}

Penelitian ini dilakukan dengan mengunakan metode survei. Penelitian ini merupakan studi kasus pada usaha tahu di Kecamatan Langsa Kota dengan pertimbangan bahwa usaha tersebut merupakan industri rumah tangga yang mempunyai potensi untuk berkembang di Kota Langsa.Objek penelitian adalah pengusaha tahu yang terdapat di Kecamatan Langsa Kota. Ruang lingkup penelitian terbatas pada pengaruh harga bahan baku, harga jual dan produksi terhadap hasil penjualan tahu di Kecamatan Langsa Kota. Penelitian dilaksanakan pada bulan Desember 2017 s/d Januari 2018.

\section{Populasi dan Sampel Penelitian}

Penelitian ini merupakan penelitian dengan metode studi kasus pada usaha pembuatan tahu yang berada di Kecamatan Langsa Kota.

\section{Metode dan Teknik Pengumpulan Data}

Data yang digunakan dalam penelitian ini dapat dibagi menjadi dua jenis berdasarkan pada pengelompokkan yaitu:

\section{Data Primer}

Data primer adalah data yang diperoleh secara langsung dari sumber data yaitu pengusaha tahu yang dijadikan objek penelitian di Kecamatan Langsa Kota melalui cara

1. Observasi yaitu metode mendapatkan data dengan cara melakukan pengamatan langsung pada objek yang diteliti sehingga diperoleh gambaran yang jelas mengenai masalah yang dihadapi.

2. Wawancara yaitu metode mendapatkan data dengan cara melakukan tanya jawab secara langsung dengan pihak-pihak yang bersangkutan guna memperoleh data dan keterangan yang menunjang analisis dalam penelitian.

3. Kuisioner yaitu metode mendapatkan data dengan cara menyebarkan daftar pertanyaan kepada responden yang dijadikan sebagai sampel penelitian.

\section{Data Sekunder}

Data sekunder adalah data yang diambil secara tidak langsung dari sumber data. Metode pengumpulanya dengan cara pendokumentasian data yang telah ada di instansi terkait, buku, jurnal, laporan dan sumber media massa yang berkaitan dengan penelitian.

\section{Variabel dan Data yang Dianalisis}

a. Hasil penjualan adalah jumlah nilai total penjualan tahu dalam waktu satu tahun dengan satuan ( $\mathrm{Rp} /$ Tahun)

b. Harga bahan baku adalah harga kacang kedelai untuk proses produksi tahu dalam satuan $(\mathrm{Rp} / \mathrm{Kg})$

c. Harga Jual adalah harga jual tahu perunit dengan satuan (Rp/Papan

d. Produksi adalah produksi usaha tahu dalam bentuk tahu perpapan diukur dengan satuan (Rp/Tahun)

\section{Model Analisis dan Pengujian Hipotesis}

Data yang telah dikumpulkan di lapangan selanjutnya ditabulasi dan seterusnya diolah sesuai dengan kebutuhan analisis. Formula yang digunakan untuk mengetahui dan menguji hipotesis digunakan adalah analisis regresi linier berganda yaitu : (Sudjana, 2002 :347) dan di bantu dengan program SPSS 17.

$$
\begin{aligned}
& \mathrm{Y}=\mathrm{a}_{0}+\mathrm{a}_{1} \mathrm{X}_{1}+\mathrm{a}_{2} \mathrm{X}_{2}+\mathrm{a}_{3} \mathrm{X}_{3}+\mathrm{e} \\
& \text { Keterangan : } \\
& \mathrm{Y}=\text { Hasil penjualan }(\mathrm{Rp} / \mathrm{Tahun}) \\
& \mathrm{X}_{1}=\text { Harga bahan baku }(\mathrm{Rp} / \mathrm{Kg})
\end{aligned}
$$




$$
\begin{aligned}
& \mathrm{X}_{2}=\text { Harga Jual (Rp/Papan) } \\
& \mathrm{X}_{3}=\text { Produksi (Papan/Tahun) } \\
& \text { a0 }=\text { Konstanta } \\
& \text { a1, a2, a3 = Koefisien regregsi } \\
& \text { e }=\text { Kesalahan (error) }
\end{aligned}
$$

Untuk mengetahui pengaruh terhadap variabel bebas (X1,X2 dan X3) dengan variabel terikat (Y) dipergunakan koefisien determinasi $\left(\mathrm{R}^{2}\right)$. Untuk mengetahui pengaruh secara serempak digunakan uji $\mathrm{F}$ dan secara parsial dengan uji $\mathrm{T}$, yang dilakukan dengan komputer program SPSS 17.

\section{Hasil dan Pembahasan}

Usaha tahu di Kecamatan Langsa Kota hanya terdapat satu pengusaha. Usaha tahu tersebut terletak di Desa Paya Bujuk Blang Paseh berdiri sejak tahun 1991, nama pemilik usaha tahu tersebut adalah bapak almarhum Rusiadi dan istrinya ibu Surip. Sejak tahun 2010 pengelolaan usaha tahu tersebut dilanjutkan oleh anaknya yang bernama Peri Ramadhani hingga sekarang.

\section{Harga Bahan Baku}

Tabel 1. Rata-Rata Harga Kedelai Dari Tahun 2008-2017 di Kota Langsa

\begin{tabular}{|c|c|}
\hline Tahun & Harga Kedelai $(\mathrm{Rp} / \mathrm{Kg})$ \\
\hline 2008 & $8.000,00$ \\
2009 & $8.200,00$ \\
2010 & $9.000,00$ \\
2011 & $8.800,00$ \\
2012 & $9.200,00$ \\
2013 & $8.500,00$ \\
2014 & $7.800,00$ \\
2015 & $7.500,00$ \\
2016 & $6.900,00$ \\
2017 & $6.900,00$ \\
\hline
\end{tabular}

Sumber : Data Primer (diolah), 2018

Tabel 1 di atas dapat dilihat bahwa rata-rata harga kedelai dari tahun 2008 sampai 2017 mengalami penurunan harga di tahun 2016 dan 2017 yaitu Rp.6.900/Kg. Turun naiknya harga ini disebabkan harga kacang kedelai impor yang mengikuti turun naiknya nilai tukar rupiah terhadap dolar. Harga bahan baku tidak mempengaruhi produksi tahu pada usaha tahu di Kecamatan Langsa Kota. Hal ini
Bahan baku utama tahu yaitu kacang kedelai yang dibeli di Pasar Kota Langsa. Jenis kedelai yang digunakan adalah kedelai impor dari Amerika yang mempunyai butiran yang lebih besar dibandingkan kedelai lokal. Alasan menggunakan kedelai impor karena sulitnya mendapatkan kedelai lokal secara kontinyu dimana proses produksi dilakukan setiap hari.

Harga kedelai dari tahun ke tahun mengalami fluktuasi berdasarkan harga kedelai yang dijual di Pasar Kota Langsa. Harga kedelai mengalami fluktuasi yang ditentukan oleh mekanisme pasar yang dipengaruhi oleh nilai tukar rupiah, persediaan kedelai dunia, biaya pengangkutan dan bea masuk. Jenis kacang kedelai yang digunakan berdasarkan observasi di tempat usaha ternyata hampir seluruhnya adalah kedelai impor, yang ditandai dengan kemasan goni plastik bertuliskan produk USA (Amerika). Berikut disajikan perkembangan harga kedelai yang dibeli oleh pengusaha tahu di Kecamatan Langsa Kota 10 (sepuluh) tahun terakhir. 
berdasarkan keperluan tahu akan dibuat menjadi produk olahan lain atau untuk konsumsi. Berikut disajikan perkembangan harga jual tahu pada usaha tahu di Kecamatan Langsa Kota.

Tabel 2. Rata-Rata Harga Jual Tahu Pada Usaha Tahu di Kecamatan Langsa Kota Tahun 2008 sampai 2017

\begin{tabular}{|c|c|}
\hline Tahun & Harga Jual Tahu (Rp/Papan) \\
\hline 2008 & $22.000,00$ \\
2009 & $23.000,00$ \\
2010 & $24.000,00$ \\
2011 & $24.000,00$ \\
2012 & $24.000,00$ \\
2013 & $25.000,00$ \\
2014 & $25.000,00$ \\
2015 & $25.000,00$ \\
2016 & $28.000,00$ \\
2017 & $30.000,00$ \\
\hline
\end{tabular}

Sumber: Data Primer (diolah), 2018

Tabel 2 di atas dapat dilihat bahwa rata-rata harga jual tahu pada usaha tahu di Kecamatan Langsa Kota mengalami peningkatan setiap tahunnya. Rata-rata peningkatan adalah Rp. 1.000 sampai Rp. 3.000/papan setiap tahunnya. Pada tahun 2017 harga jual tahu adalah Rp. 30.000/papan. Harga jual tahu setiap tahun terjadi peningkatan seiring dengan peningkatan harga bahan baku, bahan bakar dan bahan tambahan lainnya yang termasuk dalam biaya produksi tahu.

\section{Produksi Tahu}

Produksi tahu mengalami fluktuasi naik turun setiap tahunya karena mengikuti permintaan konsumen dan harga bahan baku. Permintaan konsumen yang naik turun disebabkan oleh daya beli, selera dan jumlah penduduk serta banyak produk makanan olahan yang berbahan tahu. Rata-rata perkembangan produksi tahu pada usaha tahu di Kecamatan Langsa Kota dari tahun 2008 sampai 2017 disajikan pada tabel 3 berikut ini:

Tabel 3. Rata-Rata Produksi Pada Usaha Tahu di Kecamatan Langsa Kota Tahun 2008 sampai 2017

\begin{tabular}{|c|c|}
\hline Tahun & Produksi (Papan/Tahun) \\
\hline 2008 & $18.250,00$ \\
2009 & $20.075,00$ \\
2010 & $21.900,00$ \\
2011 & $20.075,00$ \\
2012 & $22.630,00$ \\
2013 & $22.265,00$ \\
2014 & $21.170,00$ \\
2015 & $20.805,00$ \\
2016 & $22.995,00$ \\
2017 & $23.725,00$ \\
\hline
\end{tabular}

Sumber : Data Primer (diolah), 2018

Tabel 3 di atas dapat dilihat rata-rata produksi tahu pada usaha tahu di
Kecamatan Langsa Kota mengalami fluktuasi setiap tahunya. Naik turunya 
produksi ini disebabkan permintaan, harga barang subtitusi dan pergeseran selera konsumen serta produk yang berbahan tahu. Produksi tahu pada tahun 2017 sebesar Rp. 23.725 papan.

\section{Hasil Penjualan Tahu}

Hasil penjualan tahu adalah seluruh penerimaan dari penjualan tahu selama satu tahun pada usaha tahu di Kecamatan Langsa Kota. Hasil penjualan ini merupakan pendapatan kotor pengusaha tahu belum dikurangi dengan biaya produksi. Total rata-rata hasil penjualan tahu pada usaha tahu di Kecamatan Langsa Kota dari tahun 2008 sampai 2017 dapat dilihat pada tabel 4 berikut ini.

Tabel 4. Rata-Rata Hasil Penjualan Pada Usaha Tahu di Kecamatan Langsa Kota dari Tahun 2008 sampai 2017

\begin{tabular}{|c|c|}
\hline Tahun & Hasil Penjualan (RP/Tahun) \\
\hline 2008 & $401.500 .000,00$ \\
2009 & $461.725 .000,00$ \\
2010 & $525.600 .000,00$ \\
2011 & $481.800 .000,00$ \\
2012 & $543.120 .000,00$ \\
2013 & $556.625 .000,00$ \\
2014 & $529.250 .000,00$ \\
2015 & $520.125 .000,00$ \\
2016 & $643.860 .000,00$ \\
2017 & $711.750 .000,00$ \\
\hline
\end{tabular}

Sumber : Data Primer (diolah), 2018

Tabel 4 dapat dilihat bahwa rata-rata hasil penjualan tahu pada usaha tahu di Kecamatan Langsa Kota mengalami fluktuasi setiap tahunnya, naik turunya hasil penjualan disebabkan karena permintaan tahu yang meningkat. Hasil penjualan tahu terbanyak pada tahun 2017 sebesar Rp. 711.750.000,/Tahun dan hasil penjualan terendah pada tahun 2008 sebesar Rp. 401.500.000,-/Tahun

\section{Analisis Data dan Pengujian Hipotesis}

Untuk menganalisis pengaruh harga bahan baku, harga jual dan produksi terhadap hasil penjualan tahu pada usaha tahu di Kecamatan Langsa Kota digunakan model analisis regresi linier berganda. Hasil analisis linier berganda diperoleh persamaan regresi sebagai berikut: $\mathrm{Y}=-5,325+0,002 \mathrm{X}_{1}+0,239 \mathrm{X}_{2}+0,221 \mathrm{X}_{3}$

Dengan interprestasi sebagai berikut:

- Koefisien regresi harga bahan baku sebesar 0,002. Artinya bila harga jual dan produksi dianggap tetap maka setiap kenaikkan harga bahan baku sebesar Rp.1.000/Kg menyebabkan hasil penjualan meningkat sebesar Rp. 200.000,- /Tahun.
- Koefisien regresi harga jual sebesar 0,239 . Artinya bila harga bahan baku dan produksi dianggap tetap maka setiap kenaikkan harga jual tahu sebesar Rp.1.000/papan akan menyebabkan hasil penjualan meningkat sebesar Rp.23.900.000,-/Tahun.

- Koefisien regresi produksi sebesar 0,221 . Artinya bila harga bahan baku dan harga jual dianggap tetap maka setiap penambahan produksi sebesar 1.000 papan / Tahun akan menyebabkan hasil penjualan meningkat sebesar Rp.22.100.000,-/Tahun.

\section{Uji $\mathbf{R}^{2}$ (Koefisien Determinasi)}

Hasil analisis data secara regresi linier berganda menghasikan nilai $\mathrm{R}^{2}$ sebesar 0,999 artinya bahwa variabel harga bahan baku, harga jual dan produksi mempengaruhi hasil penjualan pada usaha tahu di Kecamatan Langsa Kota sebesar 99,9\%. Sisanya sebesar $0,1 \%$ dipengaruhi faktor lain yang tidak dimasukan dalam model penelitian ini seperti biaya produksi, promosi, sistem pemasaran dan lain sebagainya. 


\section{Uji F (Pengaruh Serempak)}

Hasil Uji F diperoleh nilai $F_{\text {cari sebesar }}$ $1.537,8$ dengan tingkat significan 0,000 maka secara serempak variabel harga bahan baku, harga jual dan produksi berpengaruh sangat nyata terhadap hasil penjualan pada usaha tahu di Kecamatan Langsa Kota.

\section{Uji t (Pengaruh Terpisah)}

Hasil uji $t$ diperoleh nilai $t_{c a r i} X_{1}$ sebesar 0,60 dengan significan 0,954 maka secara terpisah harga bahan baku tidak berpengaruh terhadap hasil penjualan. Hasil uji t diperoleh $t_{c a r i} X_{2}$ sebesar 11,665 dengan significan 0,000 , maka secara terpisah harga jual berpengaruh sangat nyata terhadap hasil penjualan. Hasil uji $t$ diperoleh $t_{c a r i} X_{3}$ sebesar 10,274 dengan significan 0,000 maka secara terpisah produksi berpengaruh sangat nyata terhadap hasil penjualan pada usaha tahu di Kecamatan Langsa Kota

\section{DAFTAR PUSTAKA}

Anonymous, 2016. Kota Langsa Dalam Angka. BPS. Langsa

Assauri. S., 2014. Manajemen Pemasaran. RajaGarfindo Persada. Jakarta

Arifin Anwar, 2005. Pembangunan Pertanian. Rajawali. Jakarta

Bruulsema. 2003. Tehnologi Pengolahan Pangan Pembuatan Tahu. Kanisius .Yogyakarta

Cahyadi. 2007. Tahu dan Manfaatnya. Penebar Swadaya. Jakarta

Desy Anwar, 2003. Tanaman Ubi Serba Guna. Pusat Penelitian dan Pengembangan pertanian-workshop budidaya dan pemanfaatan ubi untuk bahan pangan dan energi. http://kebunubi.blogspot.com/tanamanubi-serba-guna. [6 Maret 2010]

Husein Umar, 2001. Analisis Ekonomi Usaha Mikro Pada Home Industri Keripik Ubi. Jurnal Agrijati. Cirebon

Kamaruddin, 2005. Pengantar Ilmu Ekonomi Pertanian. PT Bumi Aksara. Jakarta

Kholim, M danYuningsih. 2009. Akuntansi Biaya. UMM Press. Malang

Koswara. 2009. Membuat Aneka Tahu. Penebar Swadaya. Jakarta
Kottler, 2000. Manajemen Pemasaran : Jilid. Erlangga. Jakarta.

Mubyarto, 2002. Pengantar Ekonomi Pertanian. LP3ES. Jakarta.

Mulyadi.2009.Akuntansi Biaya. Refika Aditama. Bandung

Nazir, M. 2005. Metode Penelitian. Cetakan ke V Ghalia Indonesia, Jakarta.

Poerwadarminta, 2003. Manajemen Pemasaran: Konsep. Edisi 10. Salemba Empat Jakarta

Prawirokusumo, S. 2000. Ilmu Usaha Tani, BPIE Yogyakarta.

Purwaningsih, E. 2005. Cara Pembuatan Tahu dan Manfaat Kedelai. Penebar Swadaya. Jakarta

Santosa. 2006. Pembuatan Tempe dan Tahu Kedelai Bahan Makanan Bergizi. Kanisius. Yokyakarta. 